\title{
TOO MUCH OF A GOOD THING: DOES INTERNATIONAL EXPERIENCE VARIETY ACCELERATE OR DELAY EXECUTIVES' CAREER ADVANCEMENT?
}

\begin{abstract}
This study integrates the contradictory predictions of human-capital and social-network perspectives about the relationship between executives' international experience and speed of career advancement. We postulate that these perspectives are rather complementary, and that the relationship between international experience and time to the top follows a U-shaped form. Initially, the acquisition of international experience speeds-up executives' career progress until a threshold where the social-network costs of cross-country mobility outweigh the human-capital benefits. Our results support the U-shaped relationship. They also show that this relationship is influenced by factors at different layers of context - suggesting that contextual aspects play an important, contingent role.
\end{abstract}

\section{Keywords}

Career internationalization, International experience, CEOs, Career advancement, Upper echelons, International human resource management 


\section{Introduction}

As organizations expand across the globe, they increasingly offer international career opportunities. Empirical evidence predicts that the number of managers who take international assignments will increase by 50 percent in the next ten years (Conboye, 2013). Scholars have regarded international experience as an essential element that helps executives to effectively deal with internationalization strategy (Carpenter, Sanders, \& Gregersen, 2001; Greve, Biemann \& Ruigrok, 2015), or even as "the path to prosperity" for large organizations that have to compete in today's global business arena (Daily, Certo, \& Dalton, 2000, p. 515). While the importance of executives' international experience for multinational enterprises (MNEs) has been well documented, studies provide mixed results on whether the acquisition of experience from different countries accelerates, or delays career progress (for a review: Baruch, Dickmann, Altman \& Bournois, 2013).

On the one hand, a number of studies draw on human capital theory to argue that international experience is related to faster job promotion (Bolino, 2007). This theory implies that individuals make rational choices regarding investments in their own human capital (Becker, 1975), and thus, labor markets reward them for these investments by offering faster career advancement (Judge, Cable, Boudreau, \& Bretz, 1995). The notion of 'the more international experience the better' is further fueled by anecdotal evidence and public press coverage (Becht, 2010), posing international career mobility as a 'must-have' for today's executives. On the other hand, studies adopt a social network perspective to argue that international experience can instead delay an executive's career advancement. This stream of research builds on the premise that individuals who hold central positions in their firms are inclined to advance faster in their careers (Seibert, Kraimer, \& Linden, 2001). Employees with high cross-country mobility often lack network centrality with the firm's headquarters, owing to indirect and remote interaction with the 
central decision makers in the firm (James, 2000; Mäkelä \& Suutari, 2009). This often leads them to miss promotion opportunities (Claussen, Grohsjean, Luger, \& Probst, 2014) and take longer to reach a top managerial position (Hamori \& Koyuncu, 2011).

While prior studies have typically treated the implications of human capital and social network perspectives as contradictory, we argue that they are rather complementary in nature as they jointly allow for a more comprehensive conceptualization of the benefits and costs of top managers' career internationalization. We develop the notion of international experience variety - defined as the degree to which individuals have acquired both 'breadth' and 'length' of experience from various countries throughout their career. Integrating human capital and social network perspectives, we hypothesize a U-shaped relationship between international experience variety and time to the top. At an initial stage, the acquisition of breadth and length of international experience speeds up executives' career progress as it offers them international human capital and global networks essential for dealing with international complexity. After a given threshold, however, extensive levels of international career exposure impede individuals to develop strong network ties with the firm's headquarters owing to frequent cross-country mobility. This lack of network centrality with the firm's head office slows down an individual's career advancement and delays his or her time to the top.

Analyzing the careers of 163 CEOs in large European firms, we find support for the hypothesized U-shaped relationship. We also show that this relationship is influenced by the geographic proximity of international experience to the headquarters, the firm's degree of internationalization (DOI) and its level of industry munificence. Our study offers several contributions. First, we combine the two contradictory research streams on the implications of executives' career internationality. Arguing that the human-capital benefits and the social- 
network costs of international experience coexist, the study allows us to gain a more nuanced view of how career internationalization impacts executives' time to the top.

Second, the study responds to the calls for examining the "contingencies that affect the relationship between international experience and career advancement" (Hamori \& Koyuncu, 2011, p. 843). It demonstrates that the benefits and costs of international experience variety depend, in part, on the geographic origin (proximity to the headquarters) of international experience, as well as the internal and external contingencies that characterize the firm's environment. Third, most of existing papers adopt dichotomous approaches to conceptualizing and measuring international experience (Baruch et al., 2013). Scholars argue that a finer-grained conceptualization of international career background can advance our understanding of the longterm consequences of career internationalization (Bolino, 2007). Our international experience variety construct captures both breadth and length of an individual's international career exposure in a single variable - a feature that prior work has highlighted as key in assessing the career effects of top managers' internationalization (Baruch et al., 2013). This allows us to enhance our understanding of the continuous nature of international experience variety and its effects on executives' careers.

\section{Literature review and hypotheses}

The importance of executives' international experience as a scarce resource that helps MNEs to gain competitive advantage has been repeatedly stressed in the literature (Athanassiou \& Nigh, 2000; Carpenter et al., 2001; Nielsen \& Nielsen, 2011; Piaskowska \& Trojanowski, 2014). In this regard, studies have examined the extent to which executives who engage in international assignments are likely to develop superior strategic thinking skills (Dragoni, Oh, Tesluk, Moore \& Van Katwyk, 2014) and attain career benefits (Hamori \& Koyuncu, 2011). 
Central questions in this area include which types of international experience are more likely to benefit an individual's career progress, what firms are more suitable for international top managers, and up to which level international career exposure helps executives to quickly achieve their career aspirations (Baruch et al., 2013). In particular, some studies have focused on the breadth of international experience by conceptualizing individuals' internationality based on the number of countries in which they have worked (e.g., Black, Gregersen, \& Mendenhall, 1992). Meanwhile, others have focused on the length of international experience by placing emphasis on the time (e.g., number of years) that an executive has spent in foreign countries (e.g., Hamori \& Koyuncu, 2011). Scholars argue that in order to adequately capture the notion of career internationalization and its effects, researchers should adopt more nuanced approaches that simultaneously consider both breadth and length of individuals' international backgrounds (Baruch et al., 2013; Bolino, 2007).

In this study, we develop the notion of 'international experience variety', defined as a continuum of the degree to which an individual has acquired breadth of experience from different countries and, at the same time, has an equal distribution of length (i.e., career time) spent in each country. We believe that the concept of international experience variety is an improvement compared to past conceptualizations of career internationalization for two reasons. First, it enables us to account for the fact that contemporary global work involves a variety of job configurations with diverse demands on individuals' international presence (Baruch et al., 2013). The application of a variety construct increases conceptual clarity as it simultaneously considers the diverse experience that an individual has gained from different countries, as well as the degree to which the individual has spent an equal amount of time in each country to adequately absorb its culture and institutional norms. Second, extant research has stressed the need for conceptualizing potential curvilinear effects of international career exposure that cannot be tested 
with dichotomous approaches (Hamori \& Koyuncu, 2011; Kraimer, Shaffer \& Bolino, 2009; Schmid \& Dauth, 2014). In particular, scholars have argued that future work should consider both the benefits and costs of career internationalization, and investigate up to which level individuals can realize career-related advantages by building diverse sets of international skills and expertise ( $\mathrm{Ng}$, Eby, Sorensen \& Feldman, 2005). The international experience variety construct allows us to examine the continuous nature of international career exposure and its potential curvilinear consequences.

Further, apart from providing a finer-grained conceptualization of international experience, we also aim to advance our understanding of individuals' career development process by offering a detailed view of the role of accumulated international experience in this process. According to Dragoni et al., (2014), there is a strong need for more nuanced insights into the various factors that determine how different forms of (international) work experience translate into career outcomes. Integrating human capital and social network theories, our research framework postulates that international experience variety is related to human capital benefits and social network costs for an individual's career progress that should be considered simultaneously. It also suggests that the interplay between human capital benefits and social network costs will be affected by the nature of an individual's international experience, as well as the internal and external contingencies facing the focal firm.

\subsection{The career benefits of international experience variety: The human capital view}

Human capital theory has been regarded as one of the most relevant theoretical traditions for studying how individuals' skills and expertise influence career prospects (Sullivan, 1999). From its tenets, this theory posits that people tend to make rational choices regarding investments in their own human capital (Becker, 1975), and thus, labor markets ought to reward them for their 
investments by offering career-related advantages (Judge et al., 1995). The underlying logic is that investments in human capital lead to increased employee productivity, which justifies higher compensation levels and faster job promotion (Bolino, 2007; James, 2000).

Overall, there are two main reasons that explain why variety of international human capital is related to career benefits for executives. First, upper echelons studies have shown that international experience constitutes a scarce, rare, and inimitable resource that is essential for the effective management of a MNE (Carpenter et al., 2001; Nielsen \& Nielsen, 2011). The accumulation of experience from different countries allows top managers to develop important global management skills (Dragoni et al., 2014), and gain valuable knowledge about different markets, headquarters-subsidiary relations, and customer demands across different countries (Hermann \& Datta, 2002). Executives who have been exposed to a variety of national environments are better equipped to deal with the international complexity facing an MNE (Carpenter et al., 2001), and may therefore attain faster job promotion within the firm.

Second, international experience can also help to gain important information and tacit knowledge from external sources in different countries (Athanassiou \& Nigh, 1999). Indeed, studies have shown that international experience at the top management team (TMT) level is associated with broader external advice networks (Athanassiou \& Nigh, 2000; Collings, 2014). The wide range of international contacts and tacit knowledge acquisition leads to faster job promotion of executives with high levels of career internationalization (Suutari \& Mäkelä, 2007). Third, top managers' international human capital has been regarded as a key vehicle to signal managerial capacity and build legitimacy among international stakeholder groups (Gong, 2006). The possession of a variety of international experience signals that the top management of the firm is equipped with international human capital essential for managing the multifaceted aspects 
of an MNE (Schmid \& Dauth, 2014). These benefits drive MNEs to promote executives with international backgrounds faster to the top.

\subsection{The career costs of international experience variety: The social network view}

While human capital theory highlights the career benefits of international experience, research drawing on the social network theory suggests that international exposure may delay an individual's career progress (Hamori \& Koyuncu, 2011; Seibert et al., 2001). Scholars stress that the selection of top managers is not exclusively determined by rules of meritocracy (Mills, 1956), but is also influenced by the interpersonal ties that the individual maintains with key decision makers in the organization (Davis, 1994; Mills, 1956). When working abroad, a certain length of stay in the host country is essential for building skills that make international executives valuable for MNEs (Bolino \& Feldman, 2000; Dragoni et al., 2014). However, moving extensively to foreign countries and staying abroad for too long may act as a double-edged sword as it removes professionals from the headquarters and hinders them from building strong network ties with key actors in the firm (Suutari \& Mäkelä, 2007).

Over time, decision makers at the firm's headquarters change, and relationships between international assignees and the organization's management become weaker (Mäkelä \& Suutari, 2009). Given that social network centrality with the firm's headquarters is an important criterion for fast promotion to the organization's upper tiers of management (Hurley, Fagenson \& Sonnenfeld, 1997), international experience variety may impede an individual to develop central ties in the company, and thus, delay his or her time to the top (Hamori \& Koyuncu, 2011).

\subsection{International experience variety and time to the top: An integrative view}


Whereas prior literature has often described the human capital and social network perspectives as contradictory in explaining the impact of international experience on career advancement, we suggest that a more nuanced view can be achieved through integration. We posit that, at the initial stage, the acquisition of international experience from different countries speeds up individuals' career progress as it equips them with international human capital and also global social networks that are essential for managing the strategic complexity of the MNE. To obtain faster career progress, however, such benefits should be combined with the development of strong network ties with the firm's head office - something that is difficult to achieve at extensive levels of international experience variety owing to the frequent cross-country mobility and length of time invested in host countries.

Indeed, research on social networks inherently assumes that the costs of career internationalization mainly arise at extensive levels of international mobility, where the individual faces challenges to develop and maintain strong network ties with the firm's headquarters (Seibert et al., 2001). Social network theory distinguishes between two types of network ties that individuals can develop: (a) strong ties and (b) weak ties (Granovetter, 1983). Strong ties are characterized by durable interpersonal relationships and can only be developed through long term interaction of individuals in the same location (James, 2000; Mäkelä \& Suutari, 2009). Meanwhile, weak ties are developed over a period of short term interaction (Granovetter, 1983), and can be beneficial for an individual's career progress (Levin \& Cross, 2004). At less extensive levels of international mobility, an individual can enrich his or her network by developing weak international ties in different countries through short term interaction. To be promoted faster to the top, however, executives need to simultaneously build strong ties with central actors at the headquarters of the firm, and thus gain access to the key resources and network systems of the focal organization (Claussen et al., 2014; Hamori \& 
Koyuncu, 2011). Since the development of strong ties demands long-term direct socialization (Granovetter, 1983), and as extensive levels of international mobility imply less direct interaction between the individual and the head office of the firm (Mäkelä \& Suutari, 2009), it is expected that the human capital advantages stemming from extensive levels of international experience variety are outweighed by the corresponding social-network costs - resulting in slower career progress.

On this basis, we hypothesize that the relationship between international experience variety and time to the top follows a U-shaped form, with time to the top appearing to decrease from low to moderate levels of the international experience variety continuum, and increase from moderate to extensive levels of the international experience variety continuum.

H1. There is a U-shaped relationship between international experience variety and executives' time to the top

\subsection{Individual effects: Geographic proximity}

Apart from the breadth and length of international experience, studies argue that the choice of 'where' (i.e., the geographic location) an individual has undertaken international assignments matters in explaining the effects of career internationalization (McCall \& Hollenbeck, 2002; Van Veen, Sahib, \& Aangeenbrug, 2014). In this study, we posit that individuals at both (a) low to moderate or (b) moderate to extensive levels of the international experience variety continuum will realize faster career progress when they possess experience from geographically proximal countries. Our line of argumentation develops as follows.

First, research on stepwise internationalization implies that in order to reduce transaction costs, firms tend to mainly focus on countries in their proximal geographic periphery before expanding to distant markets (Johanson \& Vahlne, 1977). This internationalization pattern can 
affect the recruitment decisions of MNEs (Greve et al., 2015). Studies, for instance, show that even highly international organizations with dispersed economic activity around the globe tend to compose their upper tiers of management with executives who possess knowledge from geographically proximal countries (Ruigrok, Georgakakis \& Greve, 2013; Van Veen et al., 2014). This is because the selection of executives with experience from neighborhood markets enables MNEs to effectively operate in their regional-base (Ruigrok et al., 2013), reduce transaction costs, and outperform competitors on a global level (Oh \& Contractor, 2014). Even if experience from culturally (and often geographically) distant markets equips executives with more strategic thinking skills and cognitive diversity (Dragoni et al., 2014; Magnusson \& Boggs, 2006), the managerial importance of experience from proximal countries may drive MNEs to more greatly value executives with international human capital from their proximal geographic periphery. On this basis, we assume that the human capital benefits of individuals who move from low to moderate levels of the international experience variety continuum will increase under conditions of geographic proximity, resulting in faster ascent to the top (i.e., the downward side of the Ushaped relationship will flatten and result in faster promotion when the individual has gained experience from proximal countries).

Second, expatriate research shows that the larger the geographic distance (the lower the proximity) between the country of the international assignment and the home country of the firm, the greater the communication challenges between the home-office and individual expatriates (Mäkelä \& Suutari, 2009). With increasing geographic distance, international managers are confronted with higher coordination, transport, and socialization challenges that lead to difficulties in keeping connected with the firm's headquarters (McCall \& Hollenbeck, 2002). Such disadvantages of high geographic distance will increase at extensive levels of international experience variety where the individual has not spent enough time with the head office of the 
firm due to frequent cross-country mobility and extensive length of stay in foreign countries. Hence, individuals with extensive levels of international experience variety from remote countries may face greater social network centrality costs and miss fast-track promotion opportunities (Mäkelä \& Suutari, 2009). On the contrary, however, geographic proximity between the home country of the firm and the host country in which an individual is located increases ease of communication between the two parties, reduces the social-network costs at extensive levels of international experience variety, and thus results in faster career progress (i.e., the upward side of the U-shaped relationship will flatten and result in faster promotion when the individual has gained experience from proximal countries).

Synthesizing the above, we argue that executives who stay proximal to the firm's headquarters are likely to realize faster promotion to the top at both low to moderate and moderate to extensive levels of the international experience variety continuum. This argument translates into a downward shift (i.e., a flattening effect) at both sides of the U-shaped relationship under conditions of geographic proximity of international experience.

H2. The U-shaped relationship between international experience variety and executives' time to the top flattens when the individual has worked in countries that are geographically proximal to the home country of the focal firm.

\subsection{Organizational effects: Degree of internationalization}

The relevance of a firm's degree of internationalization (DOI) for executive selection decisions has been widely recognized in the extant international management and upper echelons literatures (Nielsen, 2009). Highly international MNEs face diverse competitive environments and a continuous need to respond to the demands of their international stakeholder groups (Gong, 2006). For this reason, DOI has been used in the literature as a proxy for strategic complexity that 
poses managerial challenges at the TMT level (Sanders \& Carpenter, 1998), and determines the attributes and characteristics of individuals appointed to executive positions of MNEs (Greve et al., 2015). Building on recent theorizing about matching managers to internationalization strategies (Kaczmarek \& Ruigrok, 2013), we further argue that executives at both: (a) low to moderate and (b) moderate to extensive levels of the international experience variety continuum will realize faster career advancement when they are employed by a highly international organization.

First, studies show that MNEs with high levels of DOI require executives with international knowledge and networks in order to effectively manage their global strategic portfolios (Carpenter et al., 2001; Ruigrok, et al., 2013). "From a contingency perspective, companies can best realize the benefits of executives' international experience when they have already deployed substantial international resources" (Carpenter et al., 2001, p. 280). Such anticipated resource-based advantages that highly international firms can gain from international top managers will motivate them to promote executives who accumulate experience and human capital from different countries faster to the top. In other words, highly international organizations are likely to attribute more value to executives who develop international knowhow, which will in turn increase the human capital career benefits that individuals gain as they move from low to moderate levels of international experience variety. On this basis, we suggest that the faster promotion that individuals can obtain as they move from low to moderate levels of the international experience variety continuum is more likely to be realized in firms with high DOI.

Second, the lack of network centrality with the headquarters at extensive levels of international experience variety is likely to be less of a critical disadvantage in highly international organizations. Studies show that highly international MNEs require executives who 
possess more decentralized social network ties from a large number of foreign countries (Athanassiou \& Nigh, 1999). International network ties of executives constitute a significant resource that helps firms with high DOI to generate effective advice seeking from foreign countries and manage their highly international strategic portfolios (Athanassiou \& Nigh, 2000; Banalieva \& Athanassiou, 2010). Such benefits that highly international MNEs can gain from executives with diversified international network ties, will drive them to promote individuals at extensive levels of international experience variety faster despite their lack of strong network ties with key actors in the headquarters.

Taking together the above arguments, we hypothesize that there will be a downward shift (i.e., a flattening effect) at both sides of the U-shaped relationship under conditions of high DOI. That is, executives who move from either low to moderate or moderate to extensive levels of the international experience variety continuum will realize faster career progress when they are employed by a highly international organization.

H3. The U-shaped relationship between international experience variety and executives' time to the top flattens under conditions of high DOI.

\subsection{Industry effects: Environmental munificence}

Industry munificence refers to the degree to which the industry environment of the firm supports sustained growth (Dess \& Beard, 1984). Firms operating in munificent industries are buffered from external threats, and thus, have more space available for accumulating slack resources and promoting information processing and innovation (Finkelstein, Hambrick \& Cannella, 2009). Such firms face a need for continuous expansion in order to become key players in their domain and dominate their industries (Dess \& Beard, 1984). We argue that industry 
munificence plays a key contingency role in affecting the relationship between international experience variety and time to the top.

Research shows that under conditions of industry munificence, MNEs require executives who can promote sustained foreign expansion by drawing on their diverse international knowledge from different countries (Hutzschenreuter \& Horstkotte, 2013; Nielsen \& Nielsen, 2013). Studies argue that individuals who gather experience from foreign markets possess manifold insights and creative approaches to generating international growth (Maddux \& Galinsky, 2009; Magnusson \& Boggs, 2006). They also acquire international human capital that allows them to promote innovated expansion strategies and enhance the key "foreign entry competencies" of the firm (Nielsen \& Nielsen, 2011) - something that is crucial in environments that demand continuous growth (Dess \& Beard, 1984). Due to the importance of international human capital for MNEs in munificent industries, we argue that the career advancement benefits that individuals can gain as they move from low to moderate levels of the international experience variety continuum are more likely to be realized in munificent industry contexts.

Further, the network centrality disadvantages at extensive levels of international experience variety are also likely to lessen under munificent industry conditions. The reason is that firms in munificent industries are likely to pay more attention to the strong international networks that executives with extensive levels of international experience have developed in different countries (Coombs, Mudambi \& Deeds, 2006), rather than to their lack of network centrality and connection with the firm's headquarters. To respond to the environmental requirements for sustained growth, firms in munificent industries require executives who can draw on their diverse networks to provide international social capital and information to the organization (Al-Laham \& Souitaris, 2008; Dess \& Beard, 1984). Executives with extensive levels of international experience can promote effective advice seeking from their external (i.e., 
less central) networks in foreign countries (Athanassiou \& Nigh, 2000), something that is essential for organizations in munificent industries that require to promote foreign expansion and international growth (Maddux \& Galinsky, 2009). We thus argue that even if extensive levels of international experience variety imply a lack of connection with the headquarters and slower ascent to the top, these effects lessen in munificent industries.

Synthesizing the above arguments, we hypothesize that there will be a downward shift (i.e., a flattening effect) at both sides of the U-shaped relationship under conditions of industry munificence. That is, executives who move from either (a) low to moderate or (b) moderate to extensive levels of the international experience variety continuum will realize faster career progress in firms that operate in munificent industry contexts.

H4. The U-shaped relationship between international experience variety and executives' time to the top flattens under conditions of industry munificence.

\section{Methodology}

\subsection{Sample and data collection}

Our initial sample is based on the CEOs of the 310 largest listed firms headquartered in four European countries (i.e., Switzerland, the Netherlands, Germany and the United Kingdom) as of the end of 2008. To select our sample, we first ranked all listed firms in the four countries based on their market capitalization, and the largest 100 in each country were included given that they fulfilled the following criteria: (a) they were not categorized as small and medium sized enterprises (SMEs) based on the European Union's classification (i.e., they had more than 250 employees and greater than $€ 50$ million annual revenues), (b) their primary headquarters were located in the country of the main stock exchange in which they were listed, and (c) they were not subsidiaries or owned by another larger conglomerate. Applying these criteria allowed us to 
ensure that firms in our sample are comparable in terms of firm size, are headquartered and listed in the selected countries, and are autonomous entities.

The four countries were selected for two key reasons. First, the stock exchanges in the four countries are among the leading stock exchanges in Europe. As of December 31, 2008, the Swiss Stock Exchange, the Euronext Amsterdam, the Deutsche Börse and the London Stock Exchange, were ranked among the top five European stock exchanges in terms of domestic market capitalization (World Federation of Exchanges, 2015). These reputable stock exchanges act as homes for many large international firms that attract a wide pool of CEO candidates with diverse international experience and backgrounds (Ghemawat \& Altman, 2013). This offers a suitable context for assessing the relationship between executives' career internationalization and speed of career advancement. Second, while Germany and the United Kingdom are relatively large European economies, Switzerland and the Netherlands are smaller Western European countries. Due to their smaller market size, Swiss and Dutch firms tend to internationalize early on in their lifecycle in order to gain foreign capital resources and be exposed to foreign customers (Ruigrok \& Wagner, 2003; Ruigrok, Amann \& Wagner, 2007). Having firms from large and small European countries in our sample allows us to control for potential effects of domestic market size.

Data about CEOs and top managers were collected from annual reports, corporate websites, and biographical databases. Firm and industry level data were gathered from the ThomsonOne database. To ensure validity of data collection, we first screened annual reports to identify information about the attributes and experience of executives. In cases where information was unavailable in the annual reports, we searched the company's website, and then referred to other secondary sources (e.g., Lexis Nexis, Who is Who, and Business Week). This hierarchical data collection procedure allowed us to obtain information mainly from annual reports - a valid 
source provided by the organization itself (Greve et al., 2015; Van Veen \& Marsman, 2008). Due to frequent data unavailability, 147 cases were dropped - leaving a final sample of 163 CEOs. It should be noted that the relatively low data completion rate is due to the difficulty of gathering information about CEOs' entire career histories. Indeed, this completion rate is similar to studies that use data about CEOs' and top managers' entire career backgrounds (Greve, Nielsen \& Ruigrok, 2009; Rodenbach \& Brettel, 2012). To ensure that our final sample represents the target population, we ran several Kolmogorov-Smirnov tests in Stata 13. Results show no significant differences between the final sample and the initial population in terms of foreign sales to total sales (Collins, 1990), annual revenues, and CEOs' time to the top.

\subsection{Dependent variable}

Time to the top was calculated as the total years of full-time work experience from the beginning of an individual's professional career and up to the time of the first appointment to the CEO position in the focal organization ${ }^{1}$. In cases where the year of the CEO's career start was not available, we took the latest year of graduation as the beginning of the CEO's career. Since individuals most often decide to pursue an MBA degree after they start their professional career, we did not consider MBA graduation as the year that the CEO started his or her career, but we took the year of graduation of the previous most recent academic degree as the CEO's career start. This measure of time to the top has been widely used by prior studies and has been regarded as the most suitable for calculating executives' speed of career advancement (Cappelli \& Hamori, 2005; Hamori \& Koyuncu, 2011; Sheridan, Slocum, Buda \& Thompson, 1990). Given that

\footnotetext{
${ }^{1}$ To check the robustness of our results, we also ran our analyses based on the number of years an individual took to become CEO for first time not only in the focal firm but also in any other firm in which he or she had worked before. Results of this analysis are similar to those reported in this study, with all our hypotheses significantly supported. It should be noted that prior studies in this area have measured time to the top as the time to the CEO position in the focal firm rather than in other companies in general (e.g., Cappelli \& Hamori, 2005; Hamori \& Koyuncu, 2011). To allow comparability of our results with prior studies, we keep time to the CEO position in the focal firm as our dependent variable (see Table 2). Results of our supplementary analyses with the alternative time to the top measure are available upon request from the authors.
} 
individuals undertake international assignments with the motivation to gain a faster job promotion after repatriation (Bolino, 2007), our time to the top measurement is particularly relevant for assessing the effects of international experience variety on executives' speed of career advancement.

\subsection{Independent variable}

For CEOs' international experience, we first collected data about the number of countries a CEO worked in from the year of his or her career start. Once we identified all countries in which the CEO had worked, we searched for information about the length of time the CEO spent in each country. Next, we computed the international experience variety variable using the formula suggested by Blau (1977) expressed as: $1-\sum p_{i}{ }^{2}$, where $p$ is the relative proportion of a CEO's career length (in years) spent in each respective country $i$. High scores indicate that the individual has worked in a large number of countries with an equal distribution of time spent in each country ${ }^{2}$.

The Blau Index has mainly been used in the diversity literature (for a review: Harrison \& Klein, 2007) but has not been widely applied in career advancement research. The described operationalization of the Blau Index accords with our theoretical reasoning which assumes a link between an individual's combination of breadth and length of international experience and his or her speed of career progress. Indeed, the Blau Index has been applied by several upper echelons studies which posit that a measure of distributional properties (i.e., the dispersion or variety over

\footnotetext{
${ }^{2}$ To ensure that our results are not driven either by breadth or length of international experience in isolation, we ran supplementary Poisson analyses for breadth and length of international experience separately. Our results show that the quadratic U-shaped relationship is significantly supported with either breadth or length of international experience. This indicates that our results are not driven by only one of the two components of the international experience variety variable. In addition, we also ran a correlation analysis between the two dimensions. Results show that the number of countries and the length of time abroad were significantly and strongly correlated at $\mathrm{R}=0.67$ $(\mathrm{p}<0.001)$. This confirms the assumption that these two dimensions are highly interrelated and should thus be considered in a single variable. Results of our supplementary analyses are available upon request from the authors.
} 
specified categories) rather than central tendencies, such as mean, median or proportion, are considered to be important for understanding the effects of demography on organizational and individual-level outcomes (e.g., Greve et al., 2009; Nielsen, 2009). From a conceptual viewpoint, the main advantage of our novel international experience variety measurement is that it concurrently captures both breadth and length dimensions of an individual's career internationalization.

\subsection{Moderator variables}

In this study, we use three moderator variables that are relevant to the arguments of human capital and social network theories about the relationship between international experience variety and career advancement: geographic proximity, degree of internationalization, and industry munificence. First, scholars have stressed that geographic proximity of international experience is an individual-level factor related to the international human capital and skills that executives acquire as they gain foreign experience (e.g., Dow \& Larimo, 2009; Ruigrok et al., 2013). In that vein, Dragoni et al. (2014) find that the human capital benefits of international experience are linked to the cultural (and often to the geographic) distance between the home country of the firm and the host country of the international assignment. The greater the distance the more the human capital skills of international experience (Magnusson \& Boggs, 2006; Dragoni, Tesluk, Russel \& Oh, 2009). In addition, other studies have connected geographic proximity of international experience to the ability of the individual to keep a close connection with the firm's head office (Mäkelä \& Suutari, 2009). These studies argue that the greater the geographic distance of international experience, the more the social network costs of career internationality (Bolino, 2007). These theoretical insights jointly show that geographic proximity 
of international experience is an individual-level factor that is likely to impact the trade-off between the human capital benefits and social network costs of career internationalization.

Second, the firm's degree of internationalization (DOI) was selected as a firm-level strategic indicator of the organization's need for individuals with international human and social capital (Kaczmarek \& Ruigrok, 2013; Nielsen \& Nielsen, 2011). Indeed, scholars have stressed that DOI is a key variable related to the extent to which individuals' international experience will be valued by the company (Nielsen, 2009; Schmid \& Dauth, 2014). As highly international firms need more executives with international human capital and social networks, DOI has been regarded as an important contingency that affects the relationship between international experience and career advancement (Hamori \& Koyuncu, 2011; Nielsen, 2009). Finally, industry munificence related to the degree to which the firm requires executives with diverse international human capital and social networks that enable them to promote international growth and dominate their industry (Dess \& Beard, 1984). For this reason, industry munificence is likely to play a key role on how individuals at different levels of international experience are promoted to the top (Nielsen, 2009). Taken together, looking at the above individual, organizational and industry level contingencies allow us to appreciate how important factors at different layers of context conjointly impact the trade-off between the human capital benefits and social network costs of an individual's career internationality. This allows us to obtain a holistic picture of the multifaceted nature of the relationship between international experience and executives' speed of career advancement.

The overall geographic proximity of international experience was calculated using Ghemawat's (2014) CAGE comparator. Specifically, we first took the great-circle distance score provided by CAGE (in hundreds of kilometers) between the country in which a firm is 
headquartered and each host country in which an individual CEO had worked ${ }^{3}$. Then, for CEOs who gained experience from more than one foreign country, we summed all distance scores to an overall cumulative measure of geographic distance. To turn this into a measure of geographic proximity, we reversed this variable so high scores indicate high proximity. Similar to prior international management studies, a firm's degree of internationalization (DOI) was measured as the ratio of foreign sales to total sales of the firm as of the year 2008 (Herrman \& Datta, 2002). Further, to calculate industry munificence we followed the approach suggested by Dess \& Beard (1984). Specifically, we first calculated the regression coefficient of time on the annual average sales in the main industry of a firm based on its two-digit standard industry classification (SIC) as of a five-year period (i.e., from two years before to two years after 2008), and then divided this value from the average sales of those years (Nielsen, 2009).

\subsection{Control variables}

To adequately capture the complex nature of the relationship between international experience and time to the top, we controlled for several variables in our analysis. Prior studies suggest that speed of an individual's career progress depends on the size of the organization in which this individual is employed (Hamori \& Koyuncu, 2011; Ng et al., 2005). Therefore, firm size calculated as a composite of the total sales and number of full-time employees of a company at the end of 2008 was controlled (Calof, 1994). As the two component variables did not have the same metric, we first standardized both the number of employees and total sales to take values between 0 and 1, and then summed them in a single variable of firm size (Tihanyi, Ellstrand, Daily \& Dalton, 2000). To capture stabilizing effects at high levels of firm size, we calculated the natural logarithm of this variable. In addition, TMT size measured as the exact number of TMT

\footnotetext{
${ }^{3}$ Ghemewat's (2014) CAGE comparator has measured geographic distance as the distance in kilometers between the capitals of the countries included in the comparison.
} 
members was also controlled. This variable has been regarded as important since it represents the resources that the overall executive group has at its disposal (Haleblian \& Finkelstein, 1993).

Research on executive human capital has stressed that firms tend to increasingly value CEOs with general management education, such as an MBA degree or equivalent (Murphy \& Zabojnik, 2004). We therefore controlled for CEOs' general management education - measured as a dummy variable, taking the value of 1 if the CEO had an MBA degree and 0 otherwise. As our international experience variety variable represents concentration of experience in any single country at its low levels, we also controlled for dominant experience in the home country of the firm. This variable was coded as 1 if the CEO had mainly worked in the firm's home country and 0 otherwise. Further, studies have shown that large international organizations tend to increasingly hire foreign top managers (Oxelheim, Gregoric, Randoy \& Thomson, 2013), and that CEOs with foreign nationalities are more likely to have international experience (Greve et al., 2015). We thus controlled for CEO foreign nationality - taking the value of 1 if a CEO is a foreign national and 0 otherwise. Scholars suggest that international experience acquired through tenure inside the firm may have different effects compared to experience acquired from other companies (Hamori \& Koyuncu, 2011). To account for this aspect, we also controlled for the natural logarithm of the CEO's tenure in the firm (in years).

Further, CEOs in our sample have been appointed in different years to the CEO position and under different circumstances. This may generate sample selection issues in comparing CEOs who were appointed earlier compared to those who were hired later in time. This is particularly important, as individuals in the past used to move across countries less frequently (Van Veen \& Marsman, 2008), and hence, CEOs who were appointed earlier in time may possess less international experience variety compared to those who recently assumed the CEO position. To account for this, we controlled for tenure in the CEO position measured as the natural logarithm 
of the number of years from the time that the individual was appointed for first time as CEO in the focal firm until 2008. The higher the tenure in the CEO position, the earlier in time the individual assumed the CEO's role. This variable was entirely different from the time to the top concept. For example, two CEOs may have the same time to the top (e.g., 15 years) but one was appointed ten years before 2008 and the other at the year of assessment (i.e., 2008). Adding this variable allows us to directly control for the time differences of CEO selection in our sample. Finally, as we use a multi-country sample, we controlled for country-level differences using country dummies in our analysis. This allowed us to take into account all potential exogenous country-level effects (Greve et al., 2015; Van Veen \& Marsman, 2008).

\subsection{Analytical strategy and endogeneity}

As our dependent variable is count in nature, we employed a Poisson regression technique (Greene, 2003). To account for potential systematic variance among firms in the same industry, we clustered our analysis for the primary 2-digit SIC code of each firm using the cluster command in Stata 13. Importantly, our study focuses on individuals who reached the CEO position and compares their time to the top, and thus, does not take into account the initial pool of candidates for the CEO position. This can cause potential sample selection and endogeneity issues. To control for potential endogeneity, we used a two-step Heckman (1979) procedure (Bascle, 2008). For the effective operationalization of the Heckman model, it is important to identify instrumental variables that are correlated with the independent variable (international experience variety) and exhibit no significant association with the dependent variable (time to the top) (Bascle, 2008). A suitable instrument identified in our study is the industry average of CEOs' international experience. Research shows that firms in the same industry have a tendency towards mimetic isomorphism in executive hiring decisions, as they tend to select CEOs with 
similar experiences and backgrounds (Williamson \& Cable, 2003). However, this industry-level mimetic tendency is not likely to affect speed of career advancement among CEOs in firms that operate in the same industry. Indeed, correlation analysis indicates the suitability of the selected instrument by showing that this variable is correlated with CEO international experience $(r=0.47$; $\mathrm{p}<0.001)$, and does not exhibit a significant correlation with time to the top $(r=0.05 ; \mathrm{p}>0.10)$.

At the first step of the Heckman model, we ran a Probit regression analysis with executives' international experience as a dependent variable (see Appendix). This analysis was based on a sample of both CEOs and other members of the TMT. In this vein, our analysis captures the overall internal pool of executive candidates with potential and aspirations to assume the CEO position (Finkelstein et al., 2009). After we ran the Heckman's first step Probit model, we calculated and included the inverse Mill's ratio as an additional control variable in our main analysis (see Table 2). This allowed us to control for potential endogeneity and sample selection issues (Bascle, 2008).

\section{Results}

Table 1 provides descriptive statistics and correlations, and Table 2 presents the results of the main Poisson regression. ${ }^{4}$ To detect potential multicollinearity, we ran variance inflation factor (VIF) tests in Stata 13. Results show that the highest VIF score was 3.1 with an average VIF of 1.7. This implies that our results are not driven by multicollinearity, as both scores are far below the generally accepted VIF limit of 10 (Cohen, Cohen, West \& Aiken, 2003).

\footnotetext{
${ }^{4}$ We also computed the mean, median and standard deviation of the number of countries and the length of foreign experience of CEOs in our sample. The mean number of foreign countries is 2.07 with a median of 2 and a standard deviation of 1.34. Also, the mean length of foreign experience is 5.82 years with a median of 2 and a standard deviation of 8.39 .
} 
As shown in Table 2, our control variables demonstrate largely expected associations with the dependent variable. For example, our results show that executives with general management education (i.e., those who hold an MBA degree) are likely to be promoted faster to the top. This observed relationship is in line with the arguments of Murphy \& Zabojník, (2004) that general skills (proxied as MBA education) are increasingly appreciated by the market for executive labor - thus, CEOs with an MBA degree are promoted faster to the top. In addition, our results also show that individuals who have spent the majority of their career within the home country of the firm are likely to get promoted faster than those who have mainly been located in foreign countries. This implies that individuals who mainly stay proximal to the central management of the firm get promoted on average faster to the executive suite (Hamori \& Koyuncu, 2011).

Hypothesis 1 predicts a U-shaped relationship between international experience variety and time to the top. As Table 2 shows, the curvilinear effect of international experience variety is empirically supported (with a coefficient of -0.67 and a significance level of $p<0.05$ for the independent variable and $0.90, \mathrm{p}<0.05$ for the squared term, respectively). ${ }^{5}$ Further, hypothesis 2 suggests that both sides of the U-shaped relationship flatten when individuals have gained experience from countries that are geographically proximal to the firm's headquarters. Our results substantiate this hypothesis (with a coefficient and a significance level of $0.01, \mathrm{p}<0.05$ for the interaction effect and $-0.01, \mathrm{p}<0.05$ for the interaction with the squared term, respectively). As shown in Figure 1, both the downward and upward sides of the relationship flatten under conditions of high geographic proximity of international experience. This indicates that individuals with experience from geographically proximal countries are on average promoted faster to the top at both low and extensive levels of international experience variety. At the same

\footnotetext{
${ }^{5}$ We also investigated a linear relationship between international experience variety and time to the top (see Table 2 Model 2). Results show that the linear model does not receive statistical support. This is in favor of a quadratic compared to a linear relationship, and is in line with our theoretical predictions.
} 
time, however, Figure 1 also shows that at moderate levels of international experience variety, individuals with international experience from distant markets do not significantly differ in terms of their time to the top compared to those who stay proximal to the firm's headquarters (i.e., the two lines meet at intermediate levels of the international experience variety continuum).

Hypotheses 3 and 4 propose that the U-shaped relationship between international experience variety and time to the top flattens under conditions of high DOI and industry munificence. Our results provide partial and full support these hypotheses, respectively (see Table 2). Specifically, the moderating effect of DOI is partially significant (with a coefficient and a significance level of $1.45, \mathrm{p}>0.10$ for the interaction effect and $-2.62, \mathrm{p}<0.10$ for the interaction with the squared term, respectively). In addition, the moderating effect of industry munificence receives significant support (with a coefficient and a significance level of $11.25, \mathrm{p}<0.01$ for the interaction effect and $-15.27, \mathrm{p}<0.05$ for the interaction with the squared term, respectively). We further interpret these findings in the next section.

\section{INSERT TABLES 1 AND 2 ABOUT HERE}

\section{INSERT FIGURES 1 - 3 ABOUT HERE}

\section{Discussion}

This study was inspired by the theoretical debate surrounding the relationship between international experience and executives' speed of career progress. On the one hand, human capital theorists contend that career internationalization increases executives' human capital, and thus, speeds-up time to promotion (Judge et al., 1995; Ng et al., 2005). On the contrary, research 
that draws on the social network perspective highlights the social-network centrality disadvantages of career internationalization (Mäkelä \& Suutari, 2009). Our study argues that - in isolation - neither conceptualization can fully capture the complex nature of this relationship. By integrating the two seemingly opposing theoretical streams, we develop a middle-ground framework that considers both benefits and costs of international career exposure, and argue that the relationship between international experience variety and time to the top follows a U-shaped form. Our findings also reveal that the observed U-shaped relationship is significantly influenced by the geographic origin of international experience, the firm's DOI, and its level of industry munificence. Overall, our work responds to the call for building "theoretical models that explain how the different dimensions of global work experience might influence career advancement" (Shaffer, Kraimer, Chen \& Bolino, 2012, p. 1308).

The study provides several contributions. First, we offer a step toward the reconciliation of the two contradictory theoretical streams on the relationship between international experience and executives' time to the top: (a) the one that draws on human capital theory to highlight the 'bright side' of career internationalization (Daily et al., 2000), and (b) the other that subscribes to the social network theory to underscore the dark side of international career mobility for executives' career progress (Hamori \& Koyuncu, 2011). Our theory and empirical support of the U-shaped relationship complement recent findings which show that top managers' internationalization must be considered as a double-edged sword that can be related to both beneficial, as well as detrimental effects (Kraimer et al., 2009; Schmid \& Dauth, 2014). Our findings also help to resolve the empirical inconsistency in the extant literature by consolidating work that highlights the positive (e.g., Carpenter et al., 2001; Daily et al., 2000) and negative implications (e.g., Andreason \& Kinneer, 2005; Hamori \& Koyuncu, 2011) of career internationalization. 
The reconciliation of human capital and social network theories allows us to uncover inroads between the two contradictory theoretical views. Namely, we demonstrate that the explanatory power of the two opposing theoretical perspectives depends on the respective levels of international experience variety that an individual has acquired. Human capital theory, for example, may be more informative for individuals who move from low to moderate levels of the international experience variety continuum, and who are likely to realize faster promotion to the top. At the same time, from moderate to extensive levels of international experience variety, the human capital perspective seems to increasingly lose explanatory power - as "too many international assignments no longer provide unique experiences that build new skills" (Kraimer et al., 2009, p. 30). Instead, from moderate to extensive levels of international experience variety, the social network theory gains more explanatory power - as individuals who overdo it in undertaking international assignments are likely to face network centrality costs and slower career advancement. To this end, our theory and empirical support of the U-shaped relationship stress that in medio stat virtus: that is, individuals who can benefit most from international assignments are those who avoid the extremes (i.e., very low or extensive levels of international experience variety) and keep a balance in acquiring international human capital while at the same time retaining network centrality with the firm's headquarters.

Beyond the reconciliation of human capital and social network perspectives, our study also responds to the call for gaining a nuanced understanding of the contingencies that impact the career effects of executives' international experience. Recent empirical evidence shows that individual characteristics of executives, such as their tenure inside the focal firm (Hamori \& Koyuncu, 2011), affect the impact of international assignments on the speed of career progress. We add a new element to this discussion, by investigating the moderating role of geographic proximity between the headquarters of the firm and the host country in which the individual has 
worked. As illustrated in Figure 1, individuals with experience from geographically proximal countries on average realize faster promotion to the top. Meanwhile, at intermediate levels of international experience variety, those who accumulate experience from distant countries get promoted equally fast compared to those who stay geographically close to the firm (see Figure 1). This finding provides at least partial support to the arguments of Dragoni et al., (2014) and Magnusson \& Boggs, (2006) that experience from culturally (and often geographically) distant markets enables executives to develop more advanced strategic thinking skills, and thus, to gain fast track promotion opportunities at moderate levels of international experience variety. Importantly, however, our results also show that executives who decide to go to distant countries should particularly avoid extensive levels of international experience variety, as they will face more network costs and isolation from the headquarters' central functions. Such social network costs will drive them to realize slower career progress than those with extensive levels of international experience variety from proximal countries (see Figure 1).

Our findings with regard to the flattening moderating effect of geographic proximity confirm recent empirical evidence that shows that MNEs tend to generally place particular attention on promoting executives with knowledge from their neighborhood geographic environment (Van Veen et al., 2014). Such executives can particularly help the firm to effectively operate in its home region and outperform competitors by developing a strong base in proximal countries (Ruigrok et al., 2013). Yet, given the arguments of prior work that superior strategic thinking skills can mainly be obtained from experience in culturally distant markets (Dragoni et al., 2014; Magnusson \& Boggs, 2006), it can be assumed that executives with extensive variety of experience from remote countries can also offer valuable human capital to MNEs. In this regard, our findings suggest that international organizations should develop human resource management programs that enable individuals with extensive experience from distant countries to 
keep connected with key decision makers in the firm and receive equal fast-track promotion opportunities. Such advanced leadership development programs may enable MNEs to compose their top management with executives who possess valuable international human capital from both proximal and distant markets, and thus, outperform competitors at a global level.

Apart from the individual-level effects, our study also extends prior work by showing that organizational- and industry-level contingencies significantly impact the relationship between international experience variety and time to the top. It shows that while international top managers are on average promoted faster when they are employed by highly international organizations or by firms that operate in munificent industries, executives at moderate levels of the international experience variety continuum reach the top equally fast in less international firms, as well as in firms with low munificence (see Figures 2 and 3). These observed contextual effects at the firm and industry levels provide further support of the in medio stat virtus concept. They demonstrate that executives who keep a balance and acquire neither low nor extensive levels of international experience variety are those who are going to develop vigorous skills and a central network in the firm, and thus, get promoted faster to the top regardless of the internal and external contingencies facing the organization. In addition, the steeper and more pronounced downward side of the U-shaped relationship in firms with low DOI and low munificence (see Figures 2 and 3) implies that such firms may also require and offer fast-track promotion opportunities to executives who accumulate moderate levels of international experience variety. This may be because the promotion of international executives can increase the international know-how of less international firms in dynamic industries, and enable them to effectively compete with highly international corporations that operate under industry conditions of sustained growth. 
Finally, another contribution of the study rests on our conceptualization and measurement of career internationalization. Scholars have underscored the need to move beyond binary approaches and employ concepts that accommodate a more realistic picture of the continuous and multifaceted nature of global careers (Daily et al., 2000; Hamori \& Koyuncu, 2011; Magnusson and Boggs, 2006). In this study, we add to this literature by establishing the notion of international career variety. Capturing both breadth and length of an individual's career internationalization in a single variable allows us to consider the complex nature of this construct. To this end, our study sheds further light on the career-related impact of international experience, as "the dimensions of time and breadth will have major implications for the competencies and social networks that global careerists acquire through working abroad" (Baruch et al., 2013, p. 2389).

\section{Managerial Relevance}

Our study entails managerial implications. A central debate in the international human resource management literature is how MNEs can allocate resources to international markets and, at the same time, develop talent management systems that provide individuals with opportunities for fast-track career development (Collings 2014; Claussen et al., 2014). We relate to this topic and argue that firms should develop training programs that consider both the bright and the dark side of international assignments for individuals' speed of career advancement. Specifically, our findings confirm the need for more context-specific talent management practices (Lazarova \& Cerdin, 2007) that take into consideration the internal and external environmental contingencies of the firm, as well as the potentially undesirable career consequences of low and extensive levels of international career exposure. 
Our results also contrast anecdotal evidence that supports the notion of the more international experience the better (Becht, 2010; Conboye, 2013). It offers an enhanced understanding of international assignments and their implications with regards to the speed of individual's ascent to the upper organizational echelons. Indeed, some business press portrays executives to be skeptical of frequently undertaking foreign assignments owing to the fear of losing direct connection with the firm's headquarters (Vadstein \& Gorski, 2007). To make informed decisions about whether moving abroad will ultimately accelerate - or delay - their time to promotion, individuals should consider the development of their own international human capital while making sure that they also invest time in the home country in which the firm is headquartered. In view of contemporary non-linear careers, it may be important for "pragmatic career players" (Laud \& Johnson, 2012, p. 231) to select international assignments that will help them develop superior human capital and, at the same time, gain visibility within a firm by developing knowing-whom competencies (Hamori \& Koyuncu, 2011).

It is widely recognized that the rapid development of today's economy has critical implications for leadership development. Quite simply, there is a shortage of talented managers who possess the skills and knowledge to successfully deal with the challenges arising from firms' international operations (Dragoni et al., 2014). Thus, the question of how to best groom top managers with high potential for advancement to the $\mathrm{C}$-suite is a pressing issue for many MNEs (Dragoni, Oh, VanKatwyk \& Tesluk, 2011). In this regard, our analysis suggests that some types of international experience may help to develop executive leaders faster than others. In developing highly qualified talent, firms should thus motivate individuals to develop international skills and, at the same time, keep connected with the organization's central management and its functions. 


\section{Limitations and Future Research}

The study is subject to some limitations that open promising avenues for future research. One limitation is that, due to the limited availability of information in archival sources, we cannot control for the nature of international tasks, nor for the frequency of interaction between individual assignees and the firm's headquarters. Hence, we cannot precisely cover the deep-level knowledge and human capital that executives have acquired from foreign cultures, or the actual closeness of social ties that an executive has maintained with key decision makers in the firm. Such deep level information would be difficult to obtain through archival sources. This implies that the reconciliation of human capital and social network theories can further be realized by studies that employ other research designs. For example, further work can use survey questionnaires or multiple case studies (Gibbert, Ruigrok \& Wicki, 2008) that allow to delve deeper into the actual mechanisms through which human capital and social network theories conjointly explain the impact of international experience variety. As scholars have mentioned, qualitative approaches may be required to further unravel the bright and dark sides of contemporary careers (Baruch \& Vardi, in press), and career internationalization (Maitland \& Sammartino, 2015).

Further, our study focuses on the time that an individual took to become CEO from the beginning of his or her career. Thus, we cannot provide implications about the impact of international experience on an individual's likelihood to be appointed to the CEO position. While our supplementary analysis deals with potential sample selection issues, future studies could further examine how international experience variety impacts an executive's likelihood of promotion to the CEO position. In addition, our research cannot shed light on other career-related outcomes of international exposure, such as job satisfaction or achievement of career aspirations. Speed to the top may not be the ultimate aim for many workers. Future research can go beyond 
career progress and investigate how international career variety impacts different career-related outcomes that motivate individuals to pursue international careers.

Moreover, our international experience variety concept neglects other dimensions of top management internationalization apart from breadth and length, such as international education, cultural distance or international board interlocks. By expanding our line of argumentation, future studies could investigate whether different elements of executives' career internationalization vary in their impact on career advancement. Finally, the study focuses on three key contingencies that impact the effects of international experience variety on executives' career progress. Future studies can expand our model by investigating how other contingencies, such as the frequency of communication between an expatriate and headquarters of the firm, or the cultural distance between the home country of the firm and the host country in which an executive has gained experience, impact the relationship between international experience variety and executives' ascent to the top.

\section{Conclusion}

This study concludes that international experience variety can act as a double-edged sword for executives' pace of career progress. It supports that the accumulation of experience from various countries can be beneficial up to a threshold, after which the social network costs of extensive levels of career internationalization outweigh the human capital benefits. The central message of the study is that individuals should continue to engage in international assignments but, at the same time, they should not assume that extensive levels of international mobility will necessarily lead to faster career progress. To quickly advance in their careers, executives should acquire international human capital and, at the same time, maintain strong network ties with key decision makers in the firm. In addition, they should take into consideration the kind of 
international experience they acquire (i.e., from proximal vs. distant countries), as well as the internal and external imperatives facing the firm in which they are employed. We hope that our theory and results will inspire future research on the impact of international career exposure on executives' professional development.

\section{References}

Al-Laham, A., \& Souitaris, V. (2008). Network embeddedness and new-venture internationalization: Analyzing international linkages in the German biotech industry. Journal of Business Venturing, 23, 567-586.

Andreason, A. W., \& Kinneer, K. D. (2005). Repatriation adjustment problems and the successful reintegration of expatriates and their families. Journal of Behavioral \& Applied Management, 6, 109-126.

Athanassiou, N., \& Nigh, D. (1999). The impact of U.S. company internationalization on top management team advice networks: A tacit knowledge perspective. Strategic Management Journal, 20, 83-92.

Athanassiou, N., \& Nigh, D. (2000). Internationalization, tacit knowledge and the top management teams of MNCs. Journal of International Business Studies, 31, 471-487.

Banalieva, E. R., \& Athanassiou, N. (2010). Regional and global alliance network structures of triad multinational enterprises. Multinational Business Review, 18, 1-24.

Baruch, Y., Dickmann, M., Altman, Y., \& Bournois, F. (2013). Exploring international work: Types and dimensions of global careers. International Journal of Human Resource Management, 24, 2369-2393.

Baruch, Y., \& Vardi, Y. A fresh look at the dark side of contemporary careers: Toward a realistic discourse. British Journal of Management (in press).

Bascle, G. (2008). Controlling for endogeneity with instrumental variables in strategic management research. Strategic Organization, 6, 285-327.

Becht, B. (2010). Building a company without borders. Harvard Business Review, April,103-106.

Becker, G. S. (1975). Human capital: A theoretical and empirical analysis, with special reference to education. New York: Columbia University Press.

Black, J. S., Gregersen, H. B., \& Mendenhall, M. E. (1992). Toward a theoretical framework of repatriation adjustment. Journal of International Business Studies, 23, 737-760.

Blau, P. (1977). Inequality and heterogeneity: A primitive theory of social structure. New York: Free Press. 
Bolino, M. C. (2007). Expatriate assignments and intra-organizational career success: Implications for individuals and organizations. Journal of International Business Studies, 38, 819835.

Bolino, M. C. \& Feldman, D. C. (2000). The antecedents and consequences of underemployment among expatriates. Journal of Organizational Behavior, 21, 889-911.

Calof, J. L., (1994). The relationship between firm size and export behavior revisited. Journal of International Business Studies, 25, 367-387.

Cappelli, P., \& Hamori, M. (2005). The new road to the top. Harvard Business Review, January, 25-32.

Carpenter, M. A., Sanders, W. G., \& Gregersen, H. B. (2001). Bundling human capital with organizational context: The impact of international assignment experience on multinational firm performance and CEO pay. Academy of Management Journal, 44, 493-511.

Claussen, J., Grohsjean, T., Luger, J., \& Probst, G. (2014). Talent management and career development: What it takes to get promoted. Journal of World Business, 49, 236-244.

Cohen, J., Cohen, P., West, S. G., \& Aiken, L. S. (2003). Applied Multiple Regression/Correlation Analysis for Behavioral Sciences. Hillsdale, MI: Hillsdale.

Collings, D., (2014). Integrating global mobility and global talent management: Exploring the challenges and strategic opportunities. Journal of World Business, 49, 253-261.

Collins, J. M. (1990). A market performance comparison of U.S. firms active in domestic, developed and developing countries. Journal of International Business Studies, 21, 271-287.

Conboye, J. (2013). How valuable is international work experience? Financial Times. Retrieved from www.ft.com/intl/cms/s/2/89b6ebca-3a35-11e3-9243-00144feab7de.html, Accessed on: $13 / 11 / 2014$.

Coombs, J. E., Mudambi, R., \& Deeds, D. L., (2006). An examination of the investments in U.S. biotechnology firms by foreign and domestic corporate partners. Journal of Business Venturing, $21,405-428$.

Daily, C. M., Certo, S. T., \& Dalton, D. R. (2000). International experience in the executive suite: The path to prosperity? Strategic Management Journal, 21, 515-523.

Davis, G. F., (1994). The power of corporate elite and the politics of corporate control. In: J.D. Knottnerus, \& C. Prendergast (Eds.), Current perspectives in Social Theory. Bringley, Emerald.

Dess, G. G., \& Beard, D. W. (1984). Dimensions of organizational task environments. Administrative Science Quarterly, 29, 52-73.

Dow, D., \& Larimo, J., (2009). Challenging the conceptualization and measurement of distance and international experience in entry mode research. Journal of International Marketing. 17, 7498. 
Dragoni, L., Tesluk, P. E., Russel, J. E. A., \& Oh, I. S. (2009). Understanding managerial development: Integrating developmental assignments, learning orientation, and access to developmental opportunities in predicting managerial competencies. Academy of Management Journal, 52, 731-743.

Dragoni, L., Oh, I. S., Vankatwyk, P., \& Tesluk, P. E. (2011). Developing executive leaders: The relative contribution of cognitive ability, personality, and the accumulation of work experience in predicting strategic thinking competency. Personnel Psychology, 64, 829-864.

Dragoni, L., Oh, I. S., Tesluk, P. E., Moore, O., \& VanKatwyk, P. (2014). Developing leaders' strategic thinking through global work experience: The moderating role of cultural distance. Journal of Applied Psychology, 99, 867-882.

Finkelstein, S., Hambrick, D. C., \& Cannella, A. A. (2009). Strategic leadership: Theory and research on executives, top management teams, and boards. Oxford University Press.

Ghemawat, P. (2014). CAGE comparator. Available from: http://www.ghemawat.com/cage/ Accessed on: 03/03/2015.

Ghemawat, P. \& Altman, S.A., (2013). Depth index of globalization 2013. Available from: www.ghemawat.com/Dig/Files/Depth_Index_of_Globalization_2013_(Full_Report).pdf, Accessed on 22.11.2015.

Gibbert, M., Ruigrok, W., \& Wicki, B. (2008). What passes as a rigorous case study. Strategic Management Journal, 29, 1465-1474.

Gong, Y. (2006). The impact of subsidiary top management team diversity on subsidiary performance: Knowledge and legitimacy perspectives. Management International Review, 46, 771-789.

Granovetter, M. (1983). The strength of weak ties: A network theory revisited. Sociological Theory, 1, 201-233.

Greve, P., Biemann, T., \& Ruigrok, W., (2015). Foreign executive appointments: A multilevel examination. Journal of World Business, 50, 674-686.

Greve, P., Nielsen, S., \& Ruigrok, W. (2009). Transcending borders with international top management teams: A study of European financial multinational corporations. European Management Journal, 27, 213-224.

Greene, W. H. (2003). Econometric analysis (5th ed.). Upper Saddle River, NJ: Prentice Hall.

Haleblian, J., \& Finkelstein, S. (1993). Top management team size, CEO dominance, and firm performance: The moderating roles of environmental turbulence and discretion. Academy of Management Journal, 36, 844-863.

Hamori, M., \& Koyuncu, B. (2011). Career advancement in large organizations in Europe and the United States: Do international assignments add value? International Journal of Human Resource Management, 22, 843-862. 
Harrison, D. A., \& Klein, K. J. (2007). What's the difference? Diversity constructs as separation, variety, or disparity in organizations. Academy of Management Review, 32, 1199-1228.

Heckman, J. (1979). Sample selection bias as a specification error. Econometrica, 47, 153-161.

Hermann, P., \& Datta, D. K. (2002). CEO successor characteristics and the choice of foreign market entry mode: An empirical study. Journal of International Business Studies, 33, 551-569.

Hurley, A., Fagenson, E., \& Sonnenfeld, J.A. (1997). Does cream always rise to the top? An investigation of career attainment determinants. Organizational Dynamics, 26, 67-71.

Hutzschenreuter T., \& Horstkotte, J. (2013). Performance effects of top management team demographic faultlines in the process of product diversification. Strategic Management Journal, 34, 704-726.

James, E. H. (2000). Race-related differences in promotions and support: Underlying effects of human and social capital. Organization Science, 11, 493-508.

Johanson, J., \& Vahlne, J. E. (1977). The internationalization process of the firm: A model of knowledge development and increasing foreign market commitments. Journal of International Business Studies, 8, 23-32.

Judge, T. A., Cable, D. M., Boudreau, J. W., \& Bretz, R. D. (1995). An empirical investigation of the predictors of executive career success. Personnel Psychology, 48, 485-496.

Kaczmarek, S., \& Ruigrok, W. (2013). In at the deep end of firm internationalization. Management International Review, 53, 513-534.

Kraimer, M. L., Shaffer, M. A., \& Bolino, M. C. (2009). The influence of expatriate and repatriate experience on career advancement and repatriate retention. Human Resource Management, 48, 27-47.

Laud, R. L., \& Johnson, M. (2012). Upward mobility: A typology of tactics and strategies for career advancement. Career Development International, 17, 231-254.

Lazarova, M. B., \& Cerdin, J. (2007). Revisiting repatriation concerns: Organizational support versus career and contextual influences. Journal of International Business Studies, 38, 404-429.

Levin, D., \& Cross, R. (2004). The strength of weak ties you can trust: The mediating role of trust in effective knowledge transfer. Management Science, 50, 1477-1490.

Maddux, W. W., \& Galinsky, A. D. (2009). Cultural borders and mental barriers: The relationship between living abroad and creativity. Journal of Personality and Social Psychology, 96, 1047-1061.

Magnusson, P., \& Boggs, D. J. (2006). International experience and CEO selection: An empirical study. Journal of International Management, 12, 107-125.

Mäkelä, K., \& Suutari, V. (2009). Global careers: A social capital paradox. The International Journal of Human Resource Management, 20, 992-1008. 
Maitland, E., \& Sammartino, A. (2015). Managerial cognition and internationalization. Journal of International Business Studies, 46, 733-760.

McCall, M. W., \& Hollenbeck, G. P. (2002). Developing global executives: The lessons of international experience. Harvard Business Press.

Mills, C.W. (1956). The power of elite. Oxford: Oxford University Press.

Murphy, K. J., \& Zabojník, J. (2004). CEO pay and appointments: A market-based explanation for recent trends. American Economic Review, 94, 192-196.

Ng, T. W. H., Eby, L. T., Sorensen, K. L., \& Feldman, D. C. (2005). Predictors of objective and subjective career success: A meta-analysis. Personnel Psychology, 58, 367-408.

Nielsen, B. B., \& Nielsen, S. (2011). The role of top management team international orientation in international strategic decision-making: The choice of foreign entry mode. Journal of World Business, 46, 185-193.

Nielsen, B. B., \& Nielsen, S. (2013). Top management team nationality diversity and firm performance: A multilevel study. Strategic Management Journal, 34, 373-382.

Nielsen, S. (2009). Why do top management teams look the way they do? A multilevel exploration of the antecedents of TMT heterogeneity. Strategic Organization, 7, 277-305.

Oh, C. H., \& Contractor, F. (2014). A regional perspective on multinational expansion strategies: Reconsidering the three-stage paradigm. British Journal of Management, 25, S42-S59.

Oxelheim, L., Gregoric, A., Randoy, T., \& Thomsen, S. (2013). On the internationalization of corporate boards: The case of Nordic firms. Journal of International Business Studies, 44, 173194.

Piaskowska, D., \& Trojanowski, G. (2014). Twice as Smart? The importance of managers' formative-years' International experience for their International orientation and foreign acquisition decisions. British Journal of Management, 25, 40-57.

Rodenbach, M., \& Brettel, M. (2012). CEO experience as micro-level origin of dynamic capabilities. Management Decision, 50, 611-634.

Ruigrok, W., Amann, W., \& Wagner, H. (2007). The internationalization-performance relationship at Swiss firms: A test of the S-shape and extreme degrees of internationalization. Management International Review, 47, 349-368.

Ruigrok, W., Georgakakis, D., \& Greve, P. (2013). Regionalization strategy and performance: The moderating role of industry dynamism and top management team diversity. Multinational Business Review, 21, 6-24.

Ruigrok, W., \& Wagner, H. (2003). Internationalization and performance: An organizational learning perspective. Management International Review, 43, 63-83. 
Sanders, W.M., and Carpenter, M.A. (1998). Internationalization and firm governance: The role of CEO compensation, top management team composition, and board structure. Academy of Management Journal, 41, 158-178.

Schmid, S., \& Dauth, T. (2014). Does internationalization make a difference? Stock market reaction to announcements of international top executive appointments. Journal of World Business, 49, 63-77.

Seibert, S. E., Kraimer, M. L., \& Liden, R. C. (2001). A social capital theory of career success. Academy of Management Journal, 44, 219-237.

Shaffer, M. A., Kraimer, M. L., Chen, Y. P., \& Bolino, M. C. (2012). Choices, challenges, and career consequences of global work experiences: A review and future agenda. Journal of Management, 38, 1282-1327.

Sheridan, J., Slocum, J., Buda, R., \& Thompson, R. C. (1990). Effects of corporate sponsorship and departmental power on career tournament. Academy of Management Journal, 33, 578-602.

Sullivan, S. E. (1999). The changing nature of careers. A review and research agenda. Journal of Management, 25, 457-484.

Suutari, V., \& Mäkelä, K. (2007). The career capital of managers with global careers. Journal of Managerial Psychology, 22, 628-678.

Tihanyi, L., Ellstrand, A. E., Daily, C. M., \& Dalton, D. R. (2000). Composition of the top management team and firm international diversification. Journal of Management, 26, 1157-1177.

Vadstein, V., \& Gorski, M. (2007). Trends in global mobility. Strategic Advisor, 3, 1-4.

Van Veen, K., \& Marsman, I. (2008). How international are executive boards of European MNCs? Nationality diversity in 15 European countries. European Management Journal, 26, 188198.

Van Veen, K., Sahib, P. R., \& Aangeenbrug, E. (2014). Where do international board members come from? Country-level antecedents of international board member selection in European boards. International Business Review, 23, 407-417.

Williamson, I. O., \& Cable, D. M. (2003). Organizational hiring patterns, interfirm network ties, and interorganizational imitation. Academy of Management Journal, 46, 349-358.

World Federation of Exchanges (2015). Available from: https://www.google.ch/?gws_rd=ssl\#q =world+federation+of+stock+exchanges, Accessed on: 24.11.2015. 
TABLE 1

Correlation Matrix

\begin{tabular}{|c|c|c|c|c|c|c|c|c|c|c|c|c|c|c|}
\hline Variables & Mean & S.D. & 1 & 2 & 3 & 4 & 5 & 6 & 7 & 8 & 9 & 10 & 11 & 12 \\
\hline 1. Time to top & 22.81 & 6.41 & $\sim$ & & & & & & & & & & & \\
\hline 2. Munificence & 0.10 & 0.07 & -0.03 & $\sim$ & & & & & & & & & & \\
\hline 3. DOI & 0.60 & 0.34 & 0.10 & $-0.22 *$ & $\sim$ & & & & & & & & & \\
\hline 4. Firm size (log) & 0.06 & 0.10 & 0.10 & -0.14 & 0.13 & $\sim$ & & & & & & & & \\
\hline 5. Team size & 5.75 & 2.52 & -0.06 & 0.02 & $0.27 *$ & $0.26^{*}$ & $\sim$ & & & & & & & \\
\hline 6. MBA & 0.13 & 0.34 & -0.13 & 0.06 & 0.04 & -0.00 & $0.20 *$ & $\sim$ & & & & & & \\
\hline $\begin{array}{l}\text { 7. CEO foreign } \\
\text { nationality }\end{array}$ & 0.20 & 0.40 & -0.04 & -0.05 & $0.23 *$ & -0.02 & $0.18 *$ & $0.36^{*}$ & $\sim$ & & & & & \\
\hline $\begin{array}{l}\text { 8. Tenure in the CEO } \\
\text { position (log) }\end{array}$ & 1.42 & 0.84 & $-0.20 *$ & 0.02 & 0.07 & $-0.18^{*}$ & -0.03 & -0.07 & -0.05 & $\sim$ & & & & \\
\hline $\begin{array}{l}\text { 9.CEO company tenure } \\
(\log )\end{array}$ & 2.33 & 0.91 & -0.12 & -0.05 & 0.15 & $0.22 *$ & 0.09 & -0.03 & -0.02 & $0.52 *$ & $\sim$ & & & \\
\hline $\begin{array}{l}\text { 10. Dominant exp. from } \\
\text { home country }\end{array}$ & 0.90 & 0.31 & -0.12 & 0.02 & $-0.21 *$ & 0.00 & -0.15 & $-0.29 *$ & $-0.58 *$ & 0.12 & 0.09 & $\sim$ & & \\
\hline $\begin{array}{l}\text { 11. Geographic } \\
\text { proximity }\end{array}$ & -43.10 & 66.11 & -0.13 & 0.10 & $-0.30 *$ & $-0.30 *$ & $-0.24 *$ & $-0.23 *$ & $-0.31 *$ & 0.15 & -0.13 & $0.20 *$ & $\sim$ & \\
\hline $\begin{array}{l}\text { 12. International } \\
\text { experience variety }\end{array}$ & 0.20 & 0.24 & 0.01 & -0.14 & $0.29 *$ & 0.11 & $0.22 *$ & $0.33^{*}$ & $0.65^{*}$ & -0.13 & -0.01 & $-0.38^{*}$ & $-0.68 *$ & $\sim$ \\
\hline
\end{tabular}


Table 2: Heckman $2^{\text {nd }}$ step model

Poisson regression with time to the top as dependent variable ${ }^{\mathrm{a}}$

\begin{tabular}{|c|c|c|c|c|}
\hline \multirow{3}{*}{ Intercept } & Model 1 & Model 2 & Model 3 & Model 4 \\
\hline & $3.38 * * *$ & $3.40 * * *$ & $3.50 * * *$ & $3.54 * * *$ \\
\hline & $(0.15)$ & $(0.16)$ & $(0.16)$ & $(0.16)$ \\
\hline \multirow{2}{*}{ Inverse Mill's Ratio } & 0.00 & -0.01 & -0.03 & 0.00 \\
\hline & $(0.07)$ & $(0.07)$ & $(0.08)$ & $(0.07)$ \\
\hline \multirow{2}{*}{ Munificence } & 0.22 & 0.18 & 0.10 & -0.54 \\
\hline & $(0.37)$ & $(0.39)$ & $(0.38)$ & $(0.58)$ \\
\hline \multirow{2}{*}{ DOI } & 0.09 & 0.08 & 0.10 & 0.08 \\
\hline & $(0.08)$ & $(0.08)$ & $(0.08)$ & $(0.10)$ \\
\hline Firm size $(\log )$ & $\begin{array}{c}0.16 \\
(0.24)\end{array}$ & $\begin{array}{c}0.14 \\
(0.24)\end{array}$ & $\begin{array}{c}0.11 \\
(0.23)\end{array}$ & $\begin{array}{c}0.08 \\
(0.24)\end{array}$ \\
\hline Team size & $\begin{array}{l}-0.01 \\
(0.01)\end{array}$ & $\begin{array}{l}-0.01 \\
(0.01)\end{array}$ & $\begin{array}{l}-0.01 \\
(0.01)\end{array}$ & $\begin{array}{r}-0.02 \dagger \\
(0.01)\end{array}$ \\
\hline MBA & $\begin{array}{c}-0.16 * * \\
(0.05)\end{array}$ & $\begin{array}{c}-0.15 * * \\
(0.05)\end{array}$ & $\begin{array}{c}-0.16 * * * \\
(0.05)\end{array}$ & $\begin{array}{c}-0.16 * * * \\
(0.05)\end{array}$ \\
\hline CEO foreign nationality & $\begin{array}{l}-0.10 \dagger \\
(0.06)\end{array}$ & $\begin{array}{l}-0.06 \\
(0.08)\end{array}$ & $\begin{array}{l}-0.12 \\
(0.09)\end{array}$ & $\begin{array}{r}-0.16 \dagger \\
(0.09)\end{array}$ \\
\hline Tenure in the CEO position (log) & $\begin{array}{l}-0.05 \dagger \\
(0.03)\end{array}$ & $\begin{array}{l}-0.05 \dagger \\
(0.03)\end{array}$ & $\begin{array}{l}-0.03 \\
(0.03)\end{array}$ & $\begin{array}{l}-0.06 * \\
(0.03)\end{array}$ \\
\hline CEO company tenure (log) & $\begin{array}{l}-0.02 \\
(0.03)\end{array}$ & $\begin{array}{l}-0.03 \\
(0.03)\end{array}$ & $\begin{array}{l}-0.04 \\
(0.03)\end{array}$ & $\begin{array}{l}-0.01 \\
(0.03)\end{array}$ \\
\hline $\begin{array}{l}\text { Dominant exp. in the home } \\
\text { country of the firm }\end{array}$ & $\begin{array}{c}-0.16 * * \\
(0.06)\end{array}$ & $\begin{array}{c}-0.16^{* *} \\
(0.06)\end{array}$ & $\begin{array}{c}-0.20 * * * \\
(0.06)\end{array}$ & $\begin{array}{c}-0.20 * * * \\
(0.06)\end{array}$ \\
\hline Geographic proximity & $\begin{array}{l}-0.00 \\
(0.00)\end{array}$ & $\begin{array}{r}-0.00 * \\
(0.00)\end{array}$ & $\begin{array}{l}-0.00 * \\
(0.00)\end{array}$ & $\begin{array}{c}-0.00 * * \\
(0.00)\end{array}$ \\
\hline Country dummies & Included & Included & Included & Included \\
\hline International experience variety & & $\begin{array}{l}-0.15 \\
(0.13)\end{array}$ & $\begin{array}{r}-0.67 * \\
(0.27)\end{array}$ & $\begin{array}{c}-2.70 * * \\
(0.95)\end{array}$ \\
\hline $\begin{array}{l}\text { International experience } \\
\text { variety(squared) }\end{array}$ & & & $\begin{array}{l}0.90^{*} \\
(0.40)\end{array}$ & $\begin{array}{c}4.37 * * \\
(1.49)\end{array}$ \\
\hline International experience variety $\mathrm{X}$ & & & & $0.01 *$ \\
\hline Geographic proximity & & & & $(0.01)$ \\
\hline $\begin{array}{l}\text { International experience } \\
\text { variety(squared) X Geographic } \\
\text { proximity }\end{array}$ & & & & $\begin{array}{l}-0.01 * \\
(0.01)\end{array}$ \\
\hline International experience variety $\mathrm{X}$ & & & & 1.45 \\
\hline DOI & & & & $(1.03)$ \\
\hline International experience & & & & $-2.62 \dagger$ \\
\hline variety(squared) X DOI & & & & $(1.53)$ \\
\hline International experience variety $\mathrm{X}$ & & & & $11.25 * *$ \\
\hline Munificence & & & & $(4.65)$ \\
\hline International experience & & & & $-15.27 *$ \\
\hline variety(squared) X Munificence & & & & $(6.70)$ \\
\hline Wald Chi $^{2}$ & $59.43 * * *$ & $62.62 * * *$ & $71.76 * * *$ & $128.02 * * *$ \\
\hline
\end{tabular}


Figure 1. Moderating effect of geographic proximity

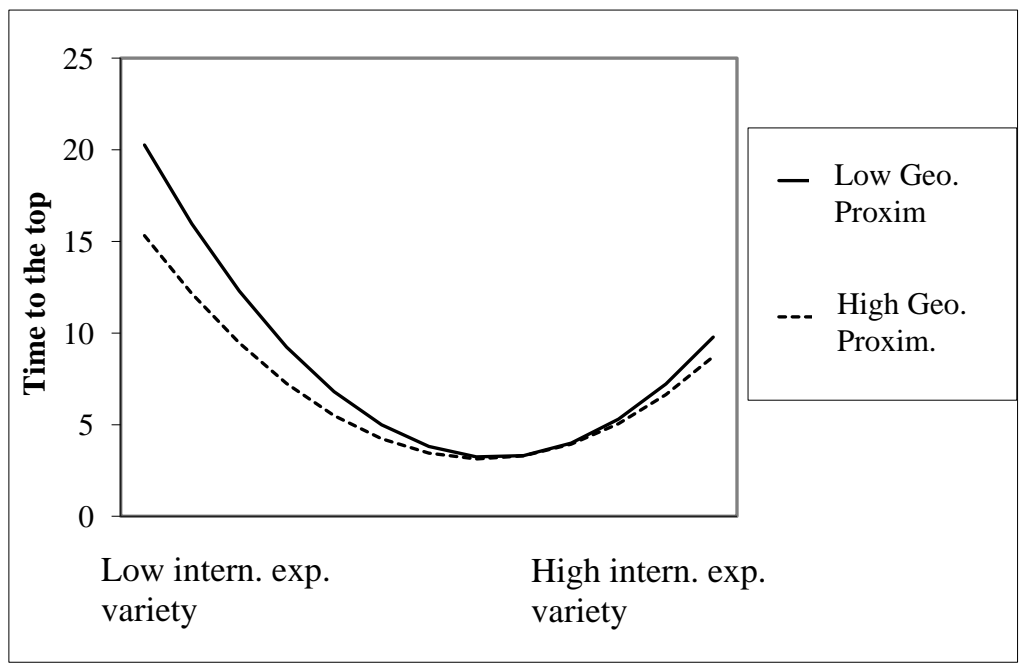

Figure 2. Moderating effect of DOI

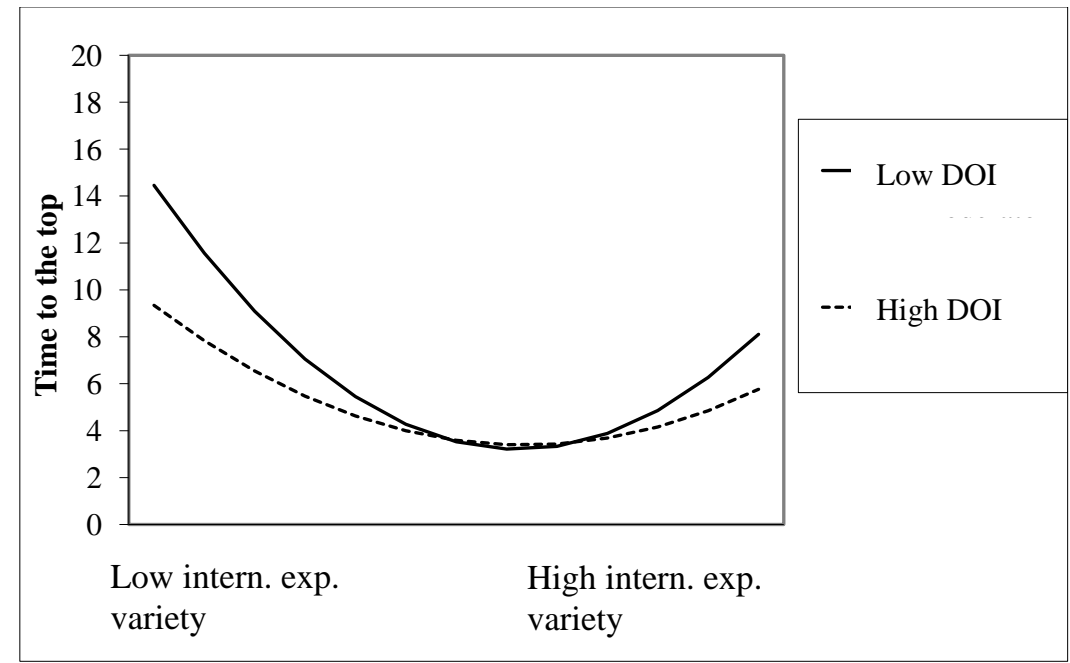

Figure 3. Moderating effect of industry munificence

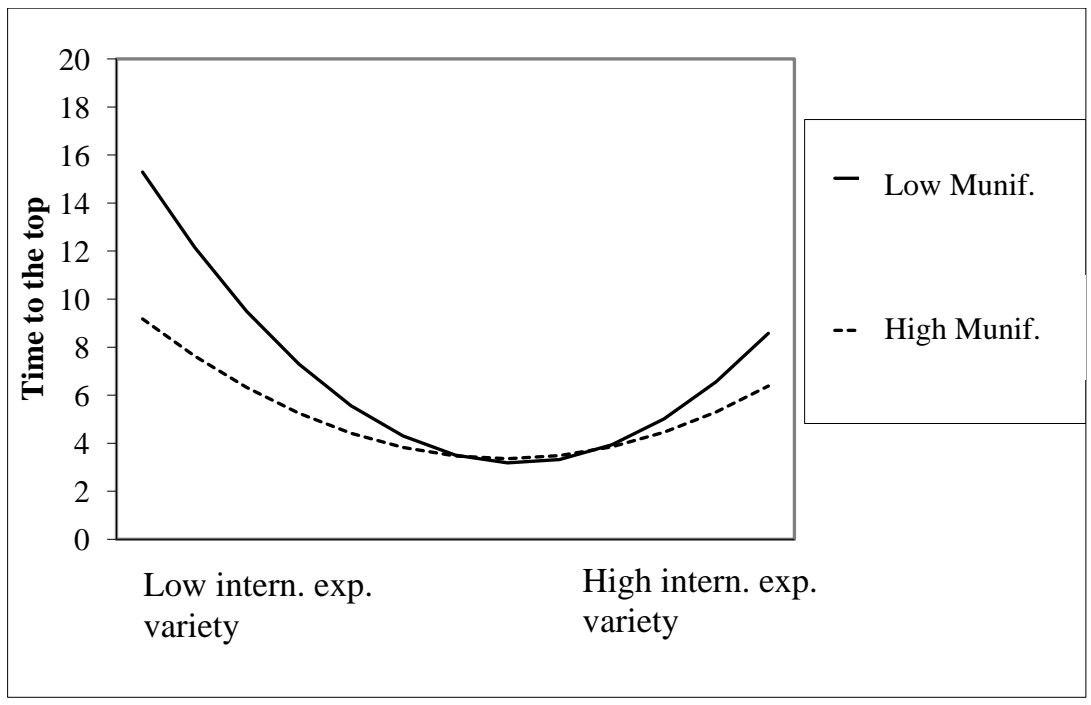




\begin{tabular}{|c|c|c|}
\hline $\begin{array}{r}\text { APPENDIX: He } \\
\text { Probit model with inte } \\
\text { as depender }\end{array}$ & $\begin{array}{l}\text { an } 1^{\text {st }} \text { Ste } \\
\text { ional exp } \\
\text { riable }\end{array}$ & erience \\
\hline & Coef. & $\underline{\text { Std.Err }}$ \\
\hline Intercept & $-1.16 * *$ & 0.38 \\
\hline $\operatorname{MBA}(\mathrm{Yes}=1)$ & $0.18 \dagger$ & 0.10 \\
\hline Gender $($ Female $=1)$ & $-0.47 *$ & 0.20 \\
\hline Foreign nationality & $0.85 * * *$ & 0.08 \\
\hline Age & 0.01 & 0.01 \\
\hline Switzerland & -0.08 & 0.09 \\
\hline Great Britain & -0.07 & 0.11 \\
\hline Netherlands & -0.05 & 0.12 \\
\hline Germany & omitted & omitted \\
\hline $\begin{array}{l}\text { Industry average } \\
\text { international experience }\end{array}$ & $2.40 * * *$ & 0.22 \\
\hline $\mathrm{Chi}^{2}$ & 333.5 & $3 * * *$ \\
\hline $\mathrm{N}=1432$ & & \\
\hline $\mathrm{p}<0.1, * \mathrm{p}<0.05, * * \mathrm{p}$ & & \\
\hline
\end{tabular}

